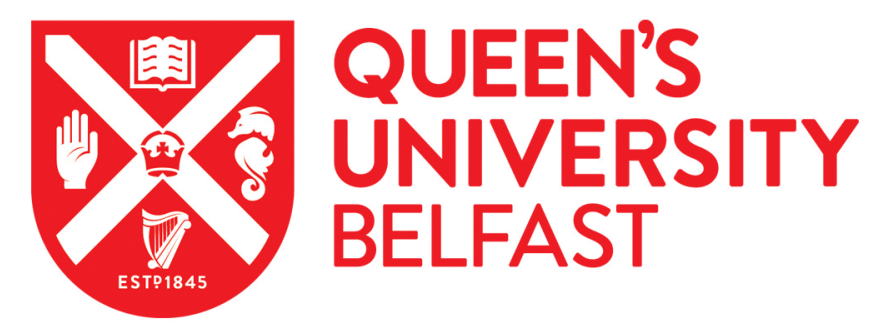

\title{
The mercury elevator in lakes - a novel vector of methylmercury transfer to fish via migratory invertebrates
}

Hall, B. D., Cobb, T. P., Graham, M. D., Leavitt, P. R., Hesslein, R. H., Kidd, K. A., \& Vogt, R. (2020). The mercury elevator in lakes - a novel vector of methylmercury transfer to fish via migratory invertebrates. Environmental Science and Technology Letters, 7(8), 579-584. https://doi.org/10.1021/acs.estlett.0c00446

Published in:

Environmental Science and Technology Letters

Document Version:

Peer reviewed version

Queen's University Belfast - Research Portal:

Link to publication record in Queen's University Belfast Research Portal

Publisher rights

Copyright 2020 American Chemical Society. This work is made available online in accordance with the publisher's policies. Please refer to any applicable terms of use of the publisher

\section{General rights}

Copyright for the publications made accessible via the Queen's University Belfast Research Portal is retained by the author(s) and / or other copyright owners and it is a condition of accessing these publications that users recognise and abide by the legal requirements associated with these rights.

Take down policy

The Research Portal is Queen's institutional repository that provides access to Queen's research output. Every effort has been made to ensure that content in the Research Portal does not infringe any person's rights, or applicable UK laws. If you discover content in the Research Portal that you believe breaches copyright or violates any law, please contact openaccess@qub.ac.uk. 
The mercury elevator in lakes - a novel vector of methylmercury transfer to fish via migratory invertebrates

Britt D. Hall ${ }^{1 *}$, Tyler P. Cobb ${ }^{1,2}$, Mark D. Graham ${ }^{1,3}$, Raymond H. Hesslein ${ }^{4}$, Karen A. Kidd $^{5}$, Richard Vogt ${ }^{1,6}$ and Peter R. Leavitt ${ }^{1,6,7}$

${ }^{1}$ Department of Biology, University of Regina, 3737 Wascana Parkway, Regina, SK, Canada S4S 0A2

${ }^{2}$ Current address; Royal Alberta Museum, 9810 103a Ave NW, Edmonton, AB, Canada, T5J 0G2

${ }^{3}$ Current address; Department of Biological Sciences, Centennial Centre of Interdisciplinary Science, University of Alberta, Edmonton, AB, Canada T6G 2E9

${ }^{4}$ Freshwater Institute, Fisheries and Oceans Canada, 501 University Avenue, Winnipeg, Canada MB R3T 2N6

${ }^{5}$ Department of Biology and School of Geography and Earth Sciences, McMaster University, 1280 Main Street West, Hamilton, ON, Canada L8S 4K1

${ }^{6}$ Institute of Environmental Change and Society, University of Regina, 3737 Wascana Parkway, Regina, SK Canada S4S 0A2

${ }^{7}$ Institute for Global Food Security, Queen's University Belfast, 19 Chlorine Gardens, Antrim, United Kingdom BT9 5DL

*corresponding author: Telephone (306) 337-2355, britt.hall@uregina.ca ORCHID: 0000-0003-4001-4952 (BDH); ORCHID 0000-0002-5619-1358 (KAK); ORCHID: 0000-0001-9805-9307 (PRL); ORCHID: 0000-0003-0327-4552 (MDG)

Keywords: Mercury, food web, trophic transfer, elevator, Leptodora, Yellow Perch, Cisco, sediments, diel vertical migration 


\begin{abstract}
Fisheries in highly productive prairie lakes of Canada and the USA frequently have fish consumption advisories due to elevated mercury concentrations. This occurrence is unexpected because such alkaline lakes often exhibit lower methylmercury ( $\mathrm{MeHg})$ concentrations in basal trophic levels than those expected in less productive basins with circumneutral $\mathrm{pH}$. As sources of $\mathrm{MeHg}$ to fish are largely dietary, components of the food web are expected to be critical controls of the transfer of $\mathrm{MeHg}$ to fish. Here we investigated how Leptodora kindtii, a large $(1.5 \mathrm{~cm})$ translucent predatory invertebrate that exhibits pronounced diel vertical migration (in sediments by day, upper water column by night) plays a key role in regulating the contamination of fish with $\mathrm{MeHg}$ in a well-studied, eutrophic, prairie lake in western Canada. Estimates of diel fluxes of invertebrate biomass and $\mathrm{MeHg}$ revealed that migratory adult Leptodora, but not other adult zooplankton or juvenile Leptodora, acted as a vector, uniquely transferring $\mathrm{MeHg}$ from presumptive deepwater sites of methylation to pelagic fish communities. This cryptic process suggests that piscivorous fish may experience greatly elevated exposure to $\mathrm{MeHg}$ even in circumstances when biogeochemical features, $\mathrm{MeHg}$ sources, and daytime food-web configuration suggest that trophic transfers should be minimal.
\end{abstract}

\title{
INTRODUCTION
}

Anthropogenic emissions of inorganic mercury (HgII) have increased its long-range transport and deposition to even remote areas. ${ }^{1,2}$ While atmospheric concentrations of total gaseous $\mathrm{Hg}$ have declined, ${ }^{3,4}$ legacy sediment stores of $\mathrm{Hg}$ represent lasting sources to water bodies that may sustain food-web advisories even after proximate pollution sources have been eliminated. ${ }^{5,6}$ Once HgII enters aquatic ecosystems, it can be transformed into methylmercury $(\mathrm{MeHg})$, usually in a benthic environment by facultative anaerobes including bacteria and archaea capable of reducing sulfate $\left(\mathrm{SO}_{4}{ }^{=}\right)$and iron $\left(\mathrm{Fe}^{3+}\right)$, or of producing methane $\left(\mathrm{CH}_{4}^{+}\right){ }^{7-10} \mathrm{MeHg}$ produced in sediment porewaters may then diffuse to surface waters, be taken up by phytoplankton and pelagic bacteria, transfer to invertebrates, and bioaccumulate in fish and other consumers reviewed in ${ }^{11}$. The pronounced and continuing threats to human health from consumption of $\mathrm{Hg}$-rich fish justifies a detailed understanding of $\mathrm{Hg}$ biogeochemistry in aquatic ecosystems. 
Fish in alkaline (high $\mathrm{pH}$ ) eutrophic lakes often exhibit lower tissue concentrations of $\mathrm{MeHg}$ than those in circumneutral unproductive basins. ${ }^{12-18}$ Lower MeHg loads in fish in productive systems may result from complex interacting processes, including differences in algal size and edibility, ${ }^{19}$ selective feeding by fish on prey with low $\mathrm{Hg}$ content, ${ }^{20}$ zooplankton mass dilution of $\mathrm{Hg}$ transfer to fish, ${ }^{21}$ local physio-chemical controls of methylation ${ }^{22}$ ), or uptake of $\mathrm{MeHg}$ by consumers cited in ${ }^{23}$. Notable exceptions to this pattern occur in eutrophic prairie lakes of North America ${ }^{24}$ and eutrophic geothermal lakes of New Zealand ${ }^{25}$, as well as contaminated sites in China ${ }^{26}$ and the northeastern $\mathrm{USA}^{27}$, where MeHg levels in fish are comparable to those observed in oligotrophic lakes.

Lakes of the Northern Great Plains of Canada and the USA often have consumption advisories for piscivorous fish due to elevated $\mathrm{Hg}$ levels e.g. ${ }^{28,29,30}$. Although Stone et al. ${ }^{31}$ noted a positive correlation between $\mathrm{pH}$, alkalinity and $\mathrm{Hg}$ concentrations in Walleye (Sander vitreus aka Stizostedion vitreum) and Northern Pike (Esox lucius), the precise mechanisms leading to this relationship are unclear, and managers lack the tools needed to predict which recreational fisheries may be vulnerable to $\mathrm{Hg}$ advisories.

Here we test a new hypothesis that elevated $\mathrm{Hg}$ content in fish in some eutrophic prairie lakes may occur because of selective consumption of migratory adults of the large, predatory cladoceran Leptodora kindtii (hereafter Leptodora). This invertebrate exploits anoxic benthic habitats during the day and is rarely sampled by conventional daytime monitoring, but is the biomass-dominant invertebrate in pelagic waters at night. ${ }^{32}$ Our research on a model prairie ecosystem suggests that this novel cryptic pathway may act as an 'elevator', both transporting $\mathrm{Hg}$ from the sedimentary source of methylation to surface waters, even in relatively deep basins (>20 m), and nearly doubling the $\mathrm{MeHg}$ content of key forage fish.

\section{MATERIALS AND METHODS}

\section{Study site}

Katepwa Lake is a moderately-deep lake (14 m average; $22 \mathrm{~m}$ at study site) located in the Qu'Appelle River Valley, a 52,000 $\mathrm{km}^{2}$ catchment spanning much of southern Saskatchewan, Canada. ${ }^{33,34}$ The lake is highly eutrophic, with elevated concentrations of 
total dissolved phosphorus (TDP; $\left.\sim 170 \mu \mathrm{g} \mathrm{L}^{-1}\right)$ and chlorophyll $a\left(\sim 25 \mu \mathrm{g} \mathrm{L}^{-1}\right)$, and a low (8.5) mass ratio of nitrogen to phosphorus (N:P). ${ }^{35}$ Although polymictic in some summers, Katepwa Lake routinely experiences anoxia below 12-15 m depth (Figure S1 in Supporting Information). ${ }^{35,36}$ Regional fish communities include Walleye, Northern Pike, Yellow Perch (Perca flavescens; henceforth Perch), Cisco (Coregonus artedi), Bigmouth Buffalo (Ictiobus cyprinellus), and White Sucker (Catostomus commersonii), although the relative proportion of fish species was not known precisely for Katepwa Lake during this study. Zooplankton community composition has been documented biweekly during the summer since 1994 and is composed of Leptodora, large-bodied Daphnia (D. galeata mendotae, D. pulicaria), omnivorous copepods (Leptodiaptomus siciloides, Diacyclops thomasi) and approximately 10-15 rotifer taxa which are not routinely quantified. ${ }^{32,35}$ All samples were collected as described below in late August 1997 on calendar day of year (DOY) 240. Sample analysis was done within two months of collection.

\section{Leptodora}

Adult Leptodora are large $(1.2-1.8 \mathrm{~cm})$ predatory cladocerans that are translucent, have small visible eyes relative to body size, and exhibit classic diel vertical migration (DVM; down by day, up by night) to avoid predation by visually-orienting fish. ${ }^{37}$ Adult Leptodora in turbid eutrophic lakes, including Katepwa Lake, remain in or near anoxic sediments during the day, but move into the upper water column at night by migrating over $20 \mathrm{~m} .{ }^{32}$ DVM is thought to be a dynamic behavior trait ${ }^{38}$ because it occurs mainly in eutrophic lakes as opposed to clear deep basins. ${ }^{39}$ In contrast, juvenile Leptodora and other smaller zooplankton exhibit little, or even mild inverse, DVM because Yellow Perch, and likely Cisco, feed in the dark using mechano-reception via their lateral-line systems. ${ }^{37}$ This mechanism cannot detect the vibrations of invertebrates smaller than adult Leptodora. ${ }^{32,40}$ Thus, while cryptic, migratory adult Leptodora can be the main prey item for young-of-the-year fish feeding offshore at night within eutrophic systems. ${ }^{32}$

\section{Sample collection}

Organic matter: Depth-integrated water for particulate organic matter (POM) was collected at a standard geo-referenced station near the centre of Katepwa Lake using 
standard protocols of the Qu'Appelle long-term ecological research program (QULTER). ${ }^{32,34,41}$ POM samples were pre-screened (153- $\mu \mathrm{m}$ mesh), filtered onto precombusted $\left(500^{\circ} \mathrm{C}, 1 \mathrm{hr}\right)$ Whatman $\mathrm{GF} / \mathrm{C}$ glass fibre filters, and stored at $-20^{\circ} \mathrm{C}$ until analysis. Pre-screening was effective at removing crustaceans and rotifers, while maintaining a representative algal assemblage characteristic of each lake. ${ }^{42}$

Zooplankton: Leptodora and other crustacean zooplankton were sampled from the central station in Katepwa Lake every $6 \mathrm{~h}$ starting at 04:00 $\mathrm{h}$ using QU-LTER protocols. ${ }^{32,35}$ Briefly, invertebrates were collected at 3-m intervals $(0-18 \mathrm{~m})$ using triplicate casts of a 12-L Schindler-Patalas trap fitted with a $243 \mathrm{~m}$ mesh net and were preserved in sugared-ethanol solution. ${ }^{32}$ In addition, vertical tows of a $20-\mathrm{cm}(243-\mu \mathrm{m}$ mesh) and a 50-cm diameter (750- $\mu \mathrm{m}$ mesh) Wisconsin net were made to collect bulk zooplankton (mainly Daphnia galeata mendotae, Diacyclops thomasi) and Leptodora, respectively, for chemical analyses. ${ }^{32,35}$ Individual Leptodora and zooplankton were measured to the nearest $0.1 \mathrm{~mm}$, isolated from bulk samples using clean techniques, and classified as juvenile, adult male, or adult female. ${ }^{32}$ These animals were frozen for $\mathrm{Hg}$ and stable isotope analyses, while zooplankton from each depth interval were enumerated at 40-x magnification using a dissecting microscope ${ }^{35}$ ). Vertical distributions of zooplankton biomass were calculated as the product of observed species' densities and mean mass per individual calculated for growth stage using a regression of dry mass versus body length. ${ }^{35}$ Masses and estimates of mean MeHg concentrations in adult and juvenile Leptodora and bulk crustacean invertebrates were used to calculate the $\mathrm{ng} \mathrm{MeHg}$ $\mathrm{L}^{-1}$ associated with zooplankton at $4 \mathrm{pm}$ CST (day) and 4 am (night).

Fish: Gill nets with multiple mesh sizes were also deployed in the upper $5 \mathrm{~m}$ of Katepwa Lake for $6 \mathrm{~h}$ each beginning at 00:00 and 12:00 h on DOY 240. Nets were set at the standard offshore site, as well as at a nearshore littoral station located $\sim 2.5 \mathrm{~km}$ distant. Individuals of young-of-the-year (YOY) Perch and Cisco were selected to be the same size and sex at each sampling site, although few Perch were collected offshore during the day, and few Cisco were collected nearshore at either sampling time. Fish samples were frozen until analyzed for stable isotopes and $\mathrm{Hg}$ content.

\section{Mercury analysis}


Zooplankton: Prior to $\mathrm{MeHg}$ analysis, zooplankton samples were freeze-dried and a minimum of $2 \mathrm{mg}$ dry weight ( $\mathrm{dw}$ ) of zooplankton was analyzed for $\mathrm{MeHg}$ concentrations using cold-vapour atomic florescence spectrometry after aqueous phase ethylation at Flett Research Ltd, Winnipeg. ${ }^{43-45}$ About 30\% of samples were run in duplicate and their $\mathrm{Hg}$ content agreed to within $2 \%$. Sample duplicates spiked with a known concentration of a $\mathrm{Hg}$ standard were run concurrent with field samples and yielded $92 \%$ of $\mathrm{Hg}$ added. All $\mathrm{Hg}$ data for zooplankton are presented as $\mathrm{ng} \mathrm{g}^{-1} \mathrm{dw}$. POM samples were not collected for $\mathrm{MeHg}$ analysis.

Fish: As $\sim 95 \%$ of $\mathrm{Hg}$ in vertebrates exists as $\mathrm{MeHg},{ }^{46,47}$ we analyzed fish only for total $\mathrm{Hg}$ ( $\mathrm{THg}$; all forms of $\mathrm{Hg}$ ). Samples were analyzed at the Freshwater Institute, Fisheries and Oceans Canada, using cold vapour atomic absorption spectroscopy (CVAAS) ${ }^{48,49}$ Approximately $0.2 \mathrm{~g}$ of isolated dorsal muscle was digested with a mixture of sulphuric and nitric acids and oxidized with potassium permanganate solution. Stannous chloride reduced $\mathrm{Hg}$ to its elemental form, which was detected by CVAAS. Recoveries of $\mathrm{Hg}$ from a certified standard reference material (National Research Council DORM-2) were always within acceptable limits $\left(4.64 \pm 0.26 \mathrm{mg} \mathrm{g}^{-1}\right)$. Concentrations of $\mathrm{Hg}$ in fish were converted from wet weights to dry weights of dorsal muscle tissue.

\section{Stable nitrogen isotope analyses}

To infer trophic position, POM, zooplankton species, Leptodora, and fish tissue were analyzed for stable isotopes of nitrogen (as $\delta^{15} \mathrm{~N}$ ) using standard methods. ${ }^{32,50}$ Zooplankton for isotope analyses were pooled to composites of 100-400 individuals of either bulk zooplankton, large species, or Leptodora. All samples were oven-dried at $70^{\circ} \mathrm{C}$ for $2 \mathrm{~h}$ and ground to a fine powder. Approximately $0.5-1.0 \mathrm{mg}$ of this tissue was analyzed at the Freshwater Institute using a VG micromass 602E dual-inlet isotope ratio mass spectrometer, modified by Europa Scientific for continuous flow operation with a He gas carrier. Stable N abundances were expressed in the standard delta notation as the deviation from the international standard of atmospheric air (\%o). Replicate samples had standard deviations of $\sim 0.2 \%$. 
Differences in $\mathrm{Hg}$ concentrations and stable isotope values were tested for significance using analysis of variance and Holm-Sidak multiple comparison analysis. Data did not require transformation based on analysis of residuals.

\section{RESULTS AND DISCUSSION}

Concentrations of $\mathrm{Hg}$ ( $\mathrm{THg}$ in fish, $\mathrm{MeHg}$ in others) increased significantly $\left(\mathrm{r}^{2}=\right.$ 0.929, $\mathrm{p}<0.001$ ) with inferred trophic level (Fig. 1A), consistent with experimental ${ }^{51,52}$ and field studies ${ }^{53}$ demonstrating that $\mathrm{MeHg}$ is delivered to fish mainly from dietary sources. Concentrations of MeHg in both adult (177.2 $\mathrm{ng} \mathrm{g}^{-1}$ ) and juvenile Leptodora $\left(148.5 \mathrm{ng} \mathrm{g}^{-1}\right)$ were significantly higher $\left(\mathrm{F}_{(5,32)}=13.608, p<0.001\right)$ than those in bulk zooplankton (Fig. 1B), as seen regularly in other lakes ${ }^{32,54}$ and reflect the fact that Leptodora consume crustacean prey ${ }^{35,40}$ and, in the case of the adults, spend up to $18 \mathrm{~h}$ in anoxic waters ${ }^{32}$ close to the expected sites of $\mathrm{Hg}$ methylation. ${ }^{55,56}$ In contrast, the near-doubling of mean THg concentrations in Perch sampled at night (454.4 $\mathrm{ng} \mathrm{g}^{-1}$ ) versus day $\left(258.5 \mathrm{ng} \mathrm{g}^{-1}\right)$ was significant $(p<0.001)$, unexpected, and suggests different pathways of exposure of these subpopulations. This pattern, along with the higher $\delta^{15} \mathrm{~N}$ values of Perch sampled at night (Fig. 1C), suggests that nocturnal prey items had higher $\mathrm{MeHg}$ concentrations than those seen in prey eaten onshore during the day.

Perch from the littoral zone were also isotopically distinct $\left(\mathrm{F}_{(5,28)}=63.006, p<0.001\right)$ from those sampled in the pelagic area (Fig. 1B). This pattern suggests that there are two distinct sub-populations of otherwise-similar fish in Katepwa Lake; those that remained continuously in the littoral zone, and those that fed offshore in the pelagic zone at night. Because Perch collected offshore at night had higher $\delta^{15} \mathrm{~N}$ than those collected during the day, and because YOY Perch were about one trophic level above adult Leptodora (Fig. 1C), we infer that pelagic Perch consumed mainly migratory adult Leptodora at night cited in ${ }^{37}$. During late summer, adult Leptodora are typically a full trophic level above large-bodied Daphnia and copepod species in these ${ }^{35}$ and other lakes, ${ }^{54}$ although that pattern was less well-developed in this short-term study. ${ }^{32}$ In contrast, Cisco, which do not migrate between near- and offshore locations, did not exhibit diurnal differences in $\delta^{15} \mathrm{~N}$ values, presumably reflecting the restriction of their feeding activity activities to the offshore pelagic zone. 
Diel changes in the density, vertical distribution, and age composition of Leptodora populations also affected the availability of $\mathrm{MeHg}$ to pelagic fishes in Katepwa Lake (Fig. 2). During the day, between 58 and $93 \%$ of $\mathrm{MeHg}$ in water-column invertebrates was found in the bulk zooplankton (D. galeata mendotae, D. thomasi), particularly in shallow $(<9 \mathrm{~m})$ surface waters (Fig. 2A). Based on their sizes $(<8 \mathrm{~mm})$, all Leptodora present in daytime surface waters were juveniles, ${ }^{32}$ life stages which are neither migratory nor contribute a large proportion (6-19\%) to the total MeHg pool. During the day, such juvenile Leptodora account for 22-42\% of MeHg contained in zooplankton (Fig. 2A). In contrast, the mostly-adult Leptodora accounted for $67-96 \%$ of $\mathrm{MeHg}$ in invertebrates at night, with little or no trend with depth despite anoxia below $\sim 12 \mathrm{~m}$ (Fig $2 \mathrm{~B}$ ). This pattern, coupled with the increased trophic level of Perch feeding at night, is consistent with our hypothesis that adult migratory Leptodora act as a unique conduit of $\mathrm{MeHg}$ to forage fish by elevating pelagic exposure to $\mathrm{MeHg}$ from otherwise inaccessible anoxic sites of $\mathrm{Hg}$ methylation.

Elevated $\mathrm{Hg}$ concentrations in the prairie lake may occur because some fish have mechanisms to feed size-selectively under low-light conditions common in turbid eutrophic lakes. ${ }^{32}$ Specifically, the ability of YOY Perch to select large cryptic prey items in the dark ${ }^{32}$ favours translocation of $\mathrm{MeHg}$ from migratory adult Leptodora to zooplanktivorous fishes, allowing the invertebrates to act as an "elevator" from anoxic profoundal habitats to the pelagic zone of even deep lakes. While we did not measure $\mathrm{MeHg}$ production in our lake, it is well-established that $\mathrm{MeHg}$ is produced in anoxic waters and sediments. ${ }^{57-59}$ In Katepwa and other Qu'Appelle lakes, other crustacean zooplankton and juvenile Leptodora were too small to be detected by fish, too large to be eaten by predatory copepods, and do not migrate. ${ }^{32}$ As well, during the day, the translucent nature of juvenile Leptodora and the other main pelagic invertebrates allows them to avoid visually-orienting predators. ${ }^{32,35}$ Such patterns are common in other eutrophic lakes with similar food-web composition, ${ }^{54,60}$ suggesting that the 'Hg elevator' may be common. Because these lakes are routinely sampled during daylight hours, such a $\mathrm{Hg}$ elevator may pass undetected in many turbid productive lakes.

These findings are consistent with over 25 years of trophic studies in the QU-LTER, $32,34,35,41$ as well as with persistent but unexplained $\mathrm{Hg}$ consumption advisories that exist 
for regional recreational fishes; ${ }^{28,30}$ however we recognize that our approach is only a snapshot of trophic interactions affecting food-web contamination with $\mathrm{MeHg}$. Zooplankton MeHg concentrations tend to respond quickly (within 10 days; see $^{55}$ for an example) to changes in $\mathrm{MeHg}$ in water. $\mathrm{MeHg}$ concentrations in adult Leptodora samples approximately 2 months (DOY 177; June 26) and 20 days (DOY 219; August 7) prior to our study were 268 and $216 \mathrm{ng} \mathrm{g}^{-1} \mathrm{dw}$, respectively, higher than those measured on DOY 240 presented here $\left(177 \pm 41 \mathrm{ng} \mathrm{g}^{-1}\right)$. This suggests that the fish $\mathrm{MeHg}$ exposure of by Leptodora in fish may be greater in other parts of the season. Trends in $\mathrm{Hg}$ concentrations in freshwater fishes are also driven by variation in $\mathrm{Hg}$ loading, in situ biogeochemistry, bioavailability, biomass dilution effects, fish diet, and organismal bioenergetics. ${ }^{2,23,59}$ As well, estimates of trophic position (as $\left.\delta^{15} \mathrm{~N}\right),{ }^{35}$ zooplankton density, ${ }^{32}$ and $\mathrm{MeHg}$ concentrations ${ }^{55,61}$ can vary on the scale of days-to-weeks. Despite these caveats, we suggest that migration of invertebrates may exert an unexpectedly strong influence over $\mathrm{Hg}$ concentrations in pelagic fish of some eutrophic lake ecosystems. Specifically, we note that the food-web of Katepwa Lake is characteristic of eutrophic lakes in this ${ }^{35,62}$ and other regions, ${ }^{63}$ suggesting that migratory adult Leptodora can act as a previously unknown elevator of $\mathrm{MeHg}$ from bottom waters to piscivores in turbid productive lakes. Knowledge of the presence of these predominantly nocturnal invertebrates and their diel excursions may help fisheries managers better assess potential risks of food-web contamination by cryptic pathways and avert unnecessary human consumption of $\mathrm{MeHg}$-rich fish.

\section{ASSOCIATED CONTENT}

\section{Supporting Information}

The Supporting Information is available free of charge at https:.....

- Depth profiles of temperature $\left({ }^{\circ} \mathrm{C}\right)$, dissolved oxygen concentrations (ppm) and conductivity $\left(\mu \mathrm{S} \mathrm{cm}^{-1}\right)$ at the deepest point of Katepwa Lake.

\section{ACKNOWLEDGEMENTS}

We thank members of the Limnology Laboratory for assistance with data collection. This work was supported by the Natural Sciences and Engineering Research Council of 
Canada Discovery Grants, the Canada Research Chair Program, Canada Foundation for Innovation, the Province of Saskatchewan, the University of Regina, and Queen's University Belfast. We acknowledge that this work was conducted in the territories of the Cree, Saulteaux, Dakota, Lakota, and Nakoda, and the homeland of the Métis/Michif Nation. We thank them for sharing the land and waters under Treaty 4.

\section{REFERENCES}

1. Weiss-Penzias, P. S.; Gay, D. A.; Brigham, M. E.; Parsons, M. T.; Gustin, M. S.; ter Schure, A., Trends in mercury wet deposition and mercury air concentrations across the U.S. and Canada. Sci. Total Environ. 2016, 568, 546-556. 10.1016/j.scitotenv.2016.01.061

2. Obrist, D.; Kirk, J. L.; Zhang, L.; Sunderland, E. M.; Jiskra, M.; Selin, N. E., A review of global environmental mercury processes in response to human and natural perturbations: Changes of emissions, climate, and land use. Ambio 2018, 47, (2), 116140. 10.1007/s13280-017-1004-9

3. Zhang, Y.; Jacob, D. J.; Horowitz, H. M.; Chen, L.; Amos, H. M.; Krabbenhoft, D. P.; Slemr, F.; St. Louis, V. L.; Sunderland, E. M., Observed decrease in atmospheric mercury explained by global decline in anthropogenic emissions. Proc. Natl. Acad. Sci. 2016, 113, (3), 526-531. 10.1073/pnas.1516312113

4. Giang, A.; Stokes, L. C.; Streets, D. G.; Corbitt, E. S.; Selin, N. E., Impacts of the Minamata Convention on Mercury Emissions and Global Deposition from Coal-Fired Power Generation in Asia. Environ. Sci. Technol. 2015, 49, (9), 5326-5335. 10.1021/acs.est.5b00074

5. Amos, H. M.; Jacob, D. J.; Streets, D. G.; Sunderland, E. M., Legacy impacts of all-time anthropogenic emissions on the global mercury cycle. Glob. Biogeochem. Cycles 2013, 27, (2), 410-421. 10.1002/gbc.20040

6. Amos, H. M.; Jacob, D. J.; Kocman, D.; Horowitz, H. M.; Zhang, Y.; Dutkiewicz, S.; Horvat, M.; Corbitt, E. S.; Krabbenhoft, D. P.; Sunderland, E. M., Global biogeochemical implications of mercury discharges from rivers and sediment burial. Environ. Sci. Technol. 2014, 48, (16), 9514-9522. 10.1021/es502134t

7. Fleming, E. J.; Mack, E. E.; Green, P. G.; Nelson, D. C., Mercury methylation from unexpected sources: Molybdate-inhibited freshwater sediments and an ironreducing bacterium. Appl. Environ. Microbiol. 2006, 72, (1), 457-464. 10.1128/AEM.72.1.457-464.2006

8. Yu, R. Q.; Flanders, J. R.; Mack, E. E.; Turner, R.; Mirza, M. B.; Barkay, T., Contribution of coexisting sulfate and iron reducing bacteria to methylmercury production in freshwater river sediments. Environ. Sci. Technol. 2012, 46, (5), 26842691. 10.1021/es2033718

9. Gilmour, C. C.; Podar, M.; Bullock, A. L.; Mitchell Grahan, A.; Brown, S.; Somenahally, A. C.; Johs, A.; Hurt, J. R. A.; Bailey, K. L.; Elias, D., A., Mercury 
methylation by novel microorganisms from new environments. Environ. Sci. Technol. 2013, 47, (20), 11810-11820. 10.1021/es403075t

10. Podar, M.; Gilmour, C. C.; Brandt, C. C.; Soren, A.; Brown, S. D.; Crable, B. R.; Palumbo, A. V.; Somenahally, A. C.; Elias, D. A., Global prevalence and distribution of genes and microorganisms involved in mercury methylation. Sci. Adv. 2015, 1, (9), e1500675-e1500675. 10.1126/sciadv.1500675

11. Eagles-Smith, C. A.; Silbergeld, E. K.; Basu, N.; Bustamante, P.; Diaz-Barriga, F.; Hopkins, W. A.; Kidd, K. A.; Nyland, J. F., Modulators of mercury risk to wildlife and humans in the context of rapid global change. Ambio 2018, 47, (2), 170-197. $10.1007 / \mathrm{s} 13280-017-1011-\mathrm{x}$

12. Poste, A. E.; Muir, D. C. G.; Guildford, S. J.; Hecky, R. E., Bioaccumulation and biomagnification of mercury in African lakes: The importance of trophic status. Sci. Total Environ. 2015, 506, 126-136. 10.1016/j.scitotenv.2014.10.094

13. Clayden, M. G.; Kidd, K. A.; Wyn, B.; Kirk, J. L.; Muir, D. C. G.; O'Driscoll, N. J., Mercury biomagnification through food webs Is affected by physical and chemical characteristics of lakes. Environ. Sci. Technol. 2013, 47, 12047-12053. 10.1021/es4022975

14. Pickhardt, P.; Folt, C. L.; Chen, C. Y.; Klaue, B.; Blum, J. D., Algal blooms reduce the uptake of toxic methylmercury in freshwater food webs. Proc. Natl. Acad. Sci. 2002, 99, (7), 4419-4423. 10.1073/pnas.072531099

15. Simoneau, M.; Lucotte, M.; Garceau, S.; Laliberte, D., Fish growth rates modulate mercury concentrations in walleye (Sander vitreus) from eastern Canadian lakes. Environ. Res. 2005, 98, (1), 73-82. 10.1016/j.envres.2004.08.002

16. Razavi, N. R.; Qu, M. Z.; Chen, D. M.; Zhong, Y.; Ren, W. W.; Wang, Y. X.; Campbell, L. M., Effect of eutrophication on mercury $(\mathrm{Hg})$ dynamics in subtropical reservoirs from a high $\mathrm{Hg}$ deposition ecoregion. Limnol. Oceanogr. 2015, 60, (2), 386401. 10.1002/lno.10036

17. Black, F. J.; Bokhutlo, T.; Somoxa, A.; Maethamako, M.; Modisaemang, O.; Kemosedile, T.; Cobb-Adams, C.; Mosepele, K.; Chimbari, M., The tropical African mercury anomaly: Lower than expected mercury concentrations in fish and human hair. Sci. Total Environ. 2011, 409, 1967-1975. 10.1016/j.scitotenv.2010.11.027

18. Driscoll, C. T.; Han, Y.-J.; Chen, C. Y.; Evers, D. C., Mercury contamination in forest and freshwater ecosystems in the northeastern United States. BioScience 2007, 57, (1), 17-28.

19. Pickhardt, P. C.; Fisher, N. S., Accumulation of inorganic and methylmercury by freshwater phytoplankton in two contrasting water bodies. Environ. Sci. Technol. 2007, 41, (1), 125-131. 10.1021/es060966w

20. Karimi, R.; Chen, C. Y.; Pickhardt, P. C.; Fisher, N. S.; Folt, C. L., Stoichiometric controls of mercury dilution by growth. Proc. Natl. Acad. Sci. 2007, 104, (18), 74777482. 10.1073/pnas.0611261104 
21. Chen, C. Y.; Folt, C. L., High plankton densities reduce mercury bioaccumulation. Environ. Sci. Technol. 2005, 39, 115-121. 10.1021/es0403007

22. Gray, J. E.; Hines, M. E., Biogeochemical mercury methylation influenced by reservoir eutrophication, Salmon Falls Creek Reservoir, Idaho, USA. Chem. Geol. 2009, 258, (3-4), 157-167. 10.1016/j.chemgeo.2008.09.023

23. Lavoie, R. A.; Jardine, T. D.; Chumchal, M. M.; Kidd, K. A.; Campbell, L. M., Biomagnification of mercury in aquatic food webs: A worldwide meta-analysis. Environ. Sci. Technol. 2013, 47, (23), 13385-13394. 10.1021/es403103t

24. Kidd, K. A.; Muir, D. C. G.; Evans, M. S.; Wang, X. W.; Whittle, M.; Swanson, H. K.; Johnston, T.; Guildford, S., Biomagnification of mercury through lake trout (Salvelinus namaycush) food webs of lakes with different physical, chemical and biological characteristics. Sci. Total Environ. 2012, 438, 135-143.

10.1016/j.scitotenv.2012.08.057

25. Verburg, P.; Hickey, C. W.; Phillips, N., Mercury biomagnification in three geothermally-influenced lakes differing in chemistry and algal biomass. Sci. Total Environ. 2014, 493, 342-354. doi:10.1016/j.scitotenv.2014.05.097

26. Long, S.-X.; Hamilton, P. B.; Yang, Y.; Wang, S.; Huang, W.-d.; Chen, C.; Tao, R., Differential bioaccumulation of mercury by zooplankton taxa in a mercurycontaminated reservoir Guizhou China. Environ. Pollut. 2018, 239, 147-160. 10.1016/j.envpol.2018.04.008

27. Todorova, S. G.; Driscoll, C. T.; Matthews, D. A.; Effler, S. W.; Hines, M. E.; Henry, E. A., Evidence for regulation of monomethyl mercury by nitrate in a seasonally stratified, eutrophic lake. Environ. Sci. Technol. 2009, 43, (17), 6572-6578. 10.1021/es900887b

28. Government of Manitoba Recreational Fish Consumption Guidelines: Southwest Manitoba. http://www.gov.mb.ca/waterstewardship/fish/mercury/southwest.html (3 March),

29. North Dakota Department of Health (Division of Water Quality) A Guide to Safe Eating of Fish Caught in North Dakota (July 2003). http://www.ndhealth.gov/WQ/SW/A_Publications.htm (3 March ),

30. Government of Saskatchewan Mercury in Saskatchewan fish: Guidelines for consumption. http://www.environment.gov.sk.ca/Default.aspx?DN=9979e82e-94b6405a-a896-2bcb3b9ea442 (3 March),

31. Stone, J. J.; McCutcheon, C. M.; Stetler, L. D.; Chipps, S. R., Interrelationships between Fish Tissue Mercury Concentrations and Water Quality for South Dakota Natural Lakes and Impoundments. Water Air Soil Pollut. 2011, 222, (1-4), 337-349. 10.1007/s11270-011-0828-3

32. Vogt, R. J.; Matthews, B.; Cobb, T. P.; Graham, M. D.; Leavitt, P. R., Food web consequences of size-based predation and vertical migration of an invertebrate predator (Leptodora kindtii). Limnol. Oceanogr. 2013, 58, (5), 1790-1801.

10.4319/10.2013.58.5.1790 
33. Hall, R. I.; Leavitt, P. R.; Quinlan, R.; Dixit, A. S.; Smol, J. P., Effects of agriculture, urbanization, and climate on water quality in the Northern Great Plains. Limnol. Oceanogr. 1999, 44, (3), 739-756. 10.1021/ac60370a016

34. Hayes, N. M.; Patoine, A.; Haig, H. A.; Simpson, G. L.; Swarbrick, V. J.; Wiik, E.; Leavitt, P. R., Spatial and temporal variation in nitrogen fixation and its importance to phytoplankton growth in phosphorus-rich lakes. Freshwater Biol. 2019, 64, 269-183. 10.1111/fwb.13214

35. Patoine, A.; Graham, M. D.; Leavitt, P. R., Spatial variation of nitrogen fixation in lakes of the northern Great Plains. Limnol. Oceanogr. 2006, 51, (4), 1665-1677.

36. Leavitt, P. R.; Brock, C. S.; Ebel, C.; Patoine, A., Landscape-scale effects of urban nitrogen on a chain of freshwater lakes in central North America. Limnol. Oceanogr. 2006, 51, 2262-2277. 10.4319/lo.2006.51.5.2262

37. Branstrator, D. K.; Holl, C. M., Planktivory by bluegill (Lepomis macrochirus) on Leptodora kindti in a small North American lake. Hydrobiologia 2000, 437, 101-106. 10.1023/A: 1026530201948

38. Vijverberg, J., Variability and possible adaptive significance of day-time vertical distribution of Leptodora kindtii (Focke) (Cladocera) in a shallow eutrophic lake. Hydrobiol. bull. 1991, 25, (1), 85-91. 10.1007/BF02259594

39. Schindler, D. W.; Noven, B., Vertical distribution and seasonal abundance of zooplankton in two shallow lakes of the experimental lakes area, northwestern Ontario. $J$. Fish. Res. Bd. Can. 1971, 28, 245-256. 10.1139/f71-035

40. Branstrator, D. K., Contrasting life histories of the predatory cladocerans Leptodora kindtii and Bythotrephes longimanus. J. Plankton Res. 2005, 27, (6), 569-585.

41. Haig, H. A.; Leavitt, P. R., The Qu'Appelle long-term ecological research program: A 26-yr hierarchical platform to study freshwater ecosystems of the northern Great Plains Limnol. Oceanogr. Bull. 2019, 28, 99-103. 10.1002/lob.10337

42. Graham, M. D. Omnivory and selective feeding by zooplankton along a lake production gradient: Complementary ${ }^{15} \mathrm{~N}$ isotope and gut pigment analyses. University of Regina, Regina, SK, 1997.

43. Bloom, N. S., Determination of picogram levels of methylmercury by aqueous phase ethylation, followed by cryogenic gas chromatography with cold vapour atomic fluorescence detection. Can. J. Fish. Aquat. Sci. 1989, 46, 1131-1140. 10.1139/f89.147

44. Horvat, M.; Bloom, N. S.; Liang, L., Comparison of distillation with other current isolation methods for the determination of methyl mercury compounds in low level environmental samples: Part I. Sediments. Anal. Chim. Acta. 1993, 281, 135-172. 10.1016/0003-2670(93)85348-N

45. Liang, L.; Horvat, M.; Bloom, N. S., An improved speciation method for mercury by GC/CVAFS after aqueous phase ethylation and room temperature precollection.

Talanta 1994, 41, (3), 371-379. 10.1016/0039-9140(94)80141-X

46. Wiener, J. G.; Krabbenhoft, D. P.; Heinz, G. H.; Scheuhammer, A. M., Ecotoxicology of mercury. In Handbook of Ecotoxicology, 2nd ed.; Hoffman, D. J.; 
Rattner, B. A.; Burton, G. A., Jr.; Cairns, J., Eds. CRC Press: Boca Raton, FL, 2003; pp 409-463.

47. Bloom, N. S., On the chemical form of mercury in edible fish and marine invertebrate tissue. Can. J. Fish. Aquat. Sci. 1992, 49, 1010-1017. 10.1139/f92-113

48. Armstrong, F. A. J.; Uthe, J. F., Semi-automatic determination of mercury in animal tissue. At. Absorp. Newsl. 1971, 10, (5), 101-103.

49. Hendzel, M. R.; Jamieson, D. M., Determination of mercury in fish. Anal. Chem. 1976, 48, 926-928. 10.1021/ac60370a016

50. Hesslein, R. H.; Capel, M. J.; Fox, D. E., Sulfur isotopes in sulfate in the inputs and outputs of a Canadian sheild watershed. Biogeochemistry 1988, 5, 263-273. 10.1007/BF 02180067

51. Hrenchuk, L. E.; Blanchfield, P. J.; Paterson, M. J.; Hintelmann, H., Dietary and waterborne mercury accumulation by Yellow Perch: a field experiment. Environ. Sci. Technol. 2012, 46, 509-516. 10.1021/es202759q

52. Hall, B. D.; Bodaly, R. A.; Fudge, R. J. P.; Rudd, J. W. M.; Rosenberg, D. M., Food as the dominant pathway of methylmercury uptake by fish. Water Air Soil Pollut. 1997, 100, 13-24. 10.1023/A:1018071406537

53. Kidd, K. A.; Hesslein, R. H.; Fudge, R. J. P.; Hallard, K. A., The influence of trophic level as measured by delta ${ }^{15} \mathrm{~N}$ on mercury concentration in freshwater organisms. Water Air Soil Pollut. 1995, 80, 1011-1015. 10.1007/978-94-011-0153-0_110

54. Lunte, C. C.; Luecke, C., Trophic interactions of Leptodora in Lake Mendota. Limnol. Oceanogr. Limnol. Oceanogr. 1990, 35, 1091-1100. 10.4319/lo.1990.35.5.1091

55. Hall, B. D.; Peech Cherewyk, K. A.; Paterson, M. J.; Bodaly, R. A., Changes in methyl mercury concentrations in zooplankton from four experimental reservoirs with differing amounts of carbon in the flooded catchments. Can. J. Fish. Aquat. Sci. 2009, 66, 1910-1919. 10.1139/F09-123

56. Paterson, M. J.; Rudd, J. W. M.; St. Louis, V. L., Increases in total and methylmercury in zooplankton following flooding of a peatland reservoir. Environ. Sci. Technol. 1998, 32, 3868-3874. 10.1021/es9803431

57. Gilmour, C. C.; Henry, E. A., Mercury methylation in aquatic systems affected by acid deposition Environ. Pollut. 1991, 71, (2-4), 131-169. 10.1016/0269-749(91)90031-Q

58. Branfireun, B. A.; Hilbert, D.; Roulet, N. T., Sinks and sources of methylmercury in a boreal catchment. Biogeochemistry 1998, 41, 277-291. 10.1023/A: 1005964603828

59. Hsu-Kim, H.; Eckley, C. S.; Achá, D.; Feng, X.; Gilmour, C. C.; Jonsson, S.; Mitchell, C. P. J., Challenges and opportunities for managing aquatic mercury pollution in altered landscapes. Ambio 2018, 47, (2), 141-169. 10.1007/s13280-017-1006-7

60. Uusitablo, L.; Horppila, J.; Eloranta, P.; Liljendahl-Nurminen, A.; Malinen, T.; Salonen, M.; Vinni, M., Leptodora kindti and flexible foraging behavior of fish factors behind the delayed biomass peak of cladocerans in Lake Hiidenvesi. Int. Rev. Hydrobiol. 2003, 88, 34-48. 10.1002/iroh.200390003 
61. Chen, C. L.; Kamman, N.; Williams, J.; Bugge, D.; Taylor, V.; Jackson, B.; Miller, E., Spatial and temporal variation in mercury bioaccumulation by zooplankton in Lake Champlain (North America). Environ. Pollut. 2012, 161, 343-349. 10.1016/j.envpol.2011.08.048

62. Starks, E.; Cooper, R. C.; Leavitt, P. R.; Wissel, B., Effects of drought and pluvial periods on fish and zooplankton communities in prairie lakes: Systematic and asystematic responses. Glob. Chang. Biol. 2014, 20, 1032-1042. 10.1111/gcb.12359

63. Kitchell, J. F., Food Web Management A Case Study of Lake Mendota. . Springer New York., 1992. 
Figure 1. Taxon-specific A: relationship between $\delta^{15} \mathrm{~N}(\%)$ and concentrations (ng $\mathrm{g}^{-1}$ $\mathrm{dw}$ ) of methylmercury ( $\mathrm{MeHg}$ ) in invertebrates and total mercury ( $\mathrm{THg}$ ) in fish, B: concentrations of $\mathrm{MeHg}$ in invertebrates and $\mathrm{THg}$ in fish, and $\mathrm{C}: \delta^{15} \mathrm{~N}$. Error bars represent 1 standard error of the mean. "Zooplankton" represent mainly Daphnia galeata mendotae, D. pulicaria, Diacyclops thomasii and Leptodiaptomus siciloides. "Leptodora" represents mainly adult individuals (> 1 $\mathrm{cm}$ length). Bars with the same lowercase letter are not significantly different. nd $=$ no data .

Figure 2. Depth from surface $(\mathrm{m})$ profiles of methylmercury $(\mathrm{MeHg})$ concentrations in invertebrates per liter of water (bars; $\mathrm{ng} \mathrm{L}^{-1}$ ) and proportion of total $\mathrm{MeHg}$ in either Leptodora or zooplankton as in Figure 1 (symbols: \%) during A: day and B: night. 
5 For Table of Contents Use Only

78

\title{
The mercury elevator in lakes - a novel vector of methylmercury transfer to fish via migratory invertebrates
}

\author{
Britt D. Hall ${ }^{1 *}$, Tyler P. Cobb ${ }^{1,2}$, Mark D. Graham ${ }^{1,3}$, Raymond H. Hesslein ${ }^{4}$, Karen A.
}

$\operatorname{Kidd}^{5}$, Richard Vogt ${ }^{1,6}$ and Peter R. Leavitt ${ }^{1,6,7}$

Table of Contents figure: Diel vertical migration of Leptodora acts as an elevator of $\mathrm{Hg}$ from anoxic habitats to fish. During the day, Yellow Perch feed on zooplankton with lower MeHg concentrations, whereas fish at night feed offshore on migratory adult Leptodora kindtii which have 3-fold higher MeHg content. These invertebrates spend the day in anoxic waters where they are inaccessible to fish.

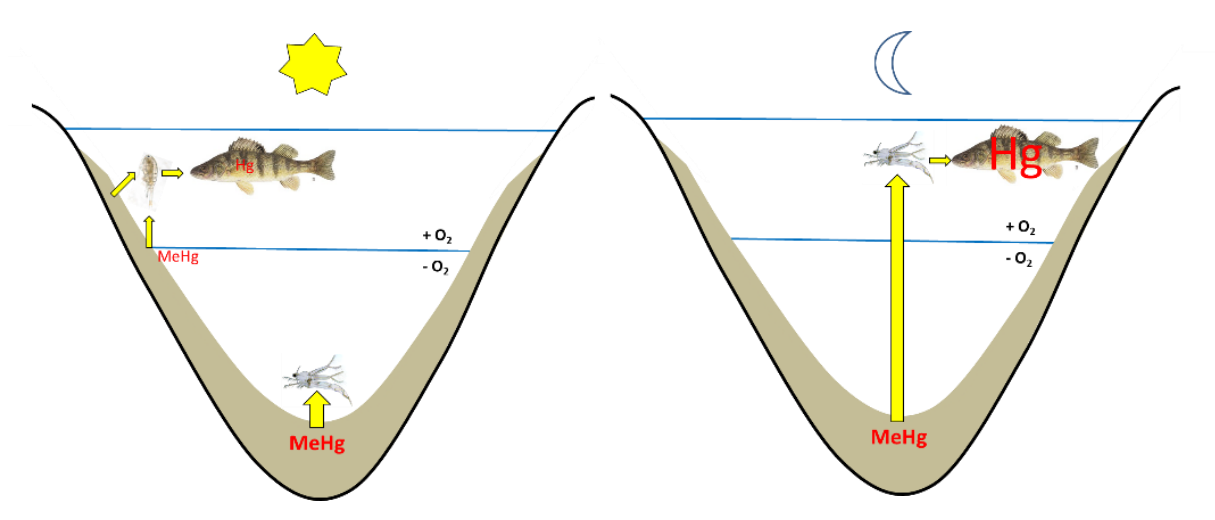


Figure 1.

21

22
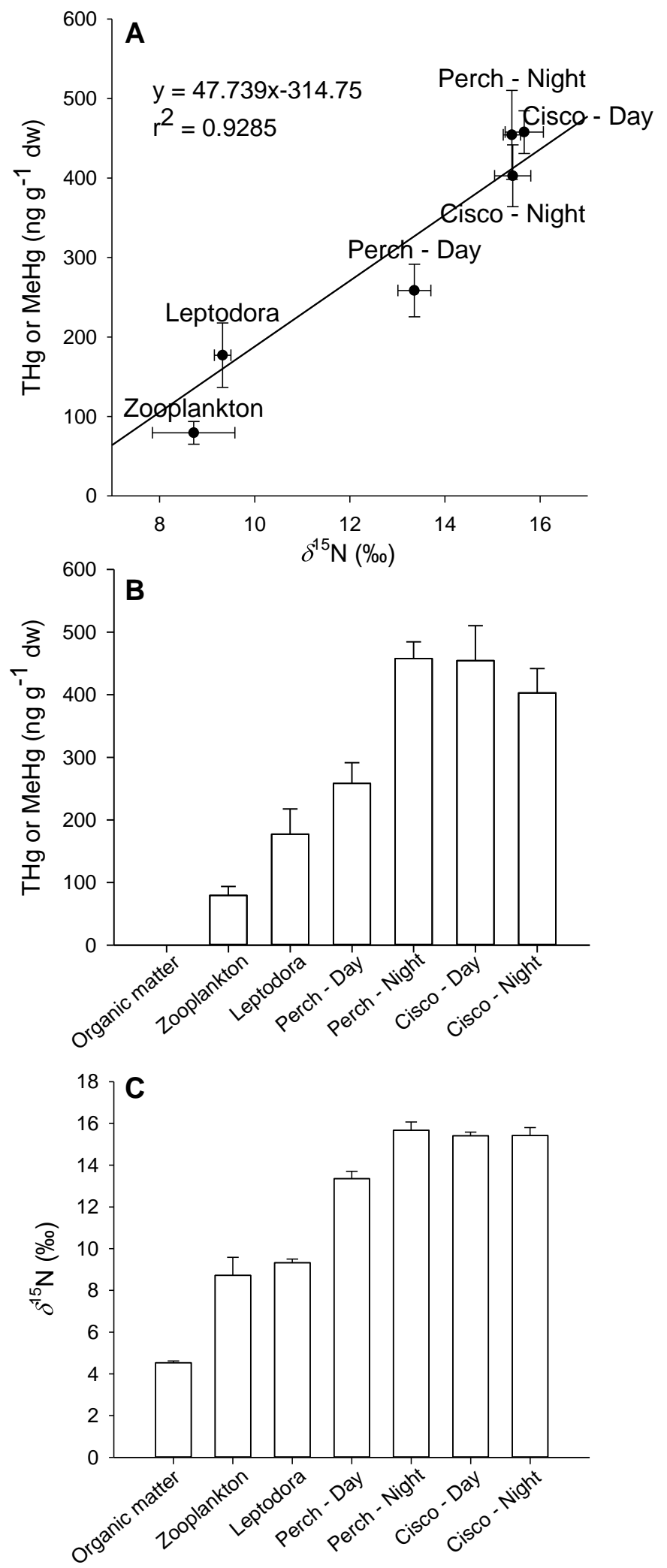
23
MeHg in invertebrates in water column (ng L-1)

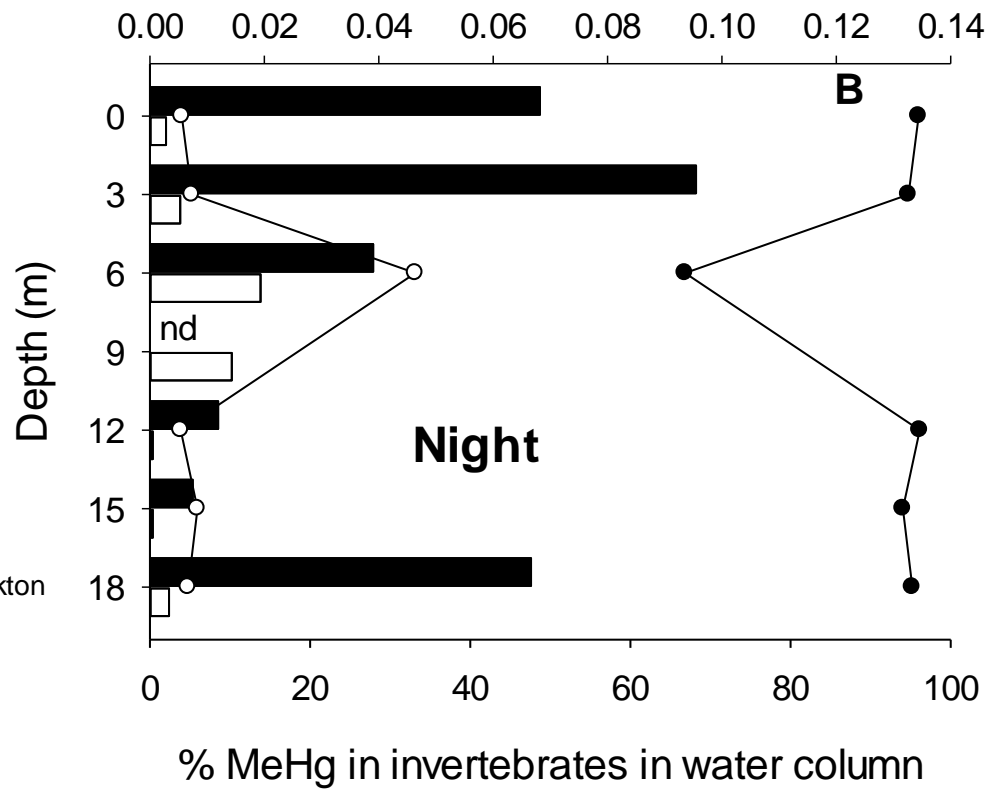

$\% \mathrm{MeHg}$ in invertebrates in water column

\section{Figure 2}

$\square$ Bulk zooplankton $\mathrm{ng} \mathrm{L}^{-1}$

$\longrightarrow \% \mathrm{MeHg}$ in Leptodora

-

18

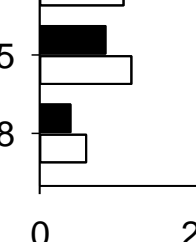

$\% \mathrm{MeHg}$ in invertebrates in water column 
40

41

42

43

44

45

46

47

48

49

50

51

52

53

54

\section{Figure S1.}

9

0

1

2

3

4

5

6

8

9

0

1
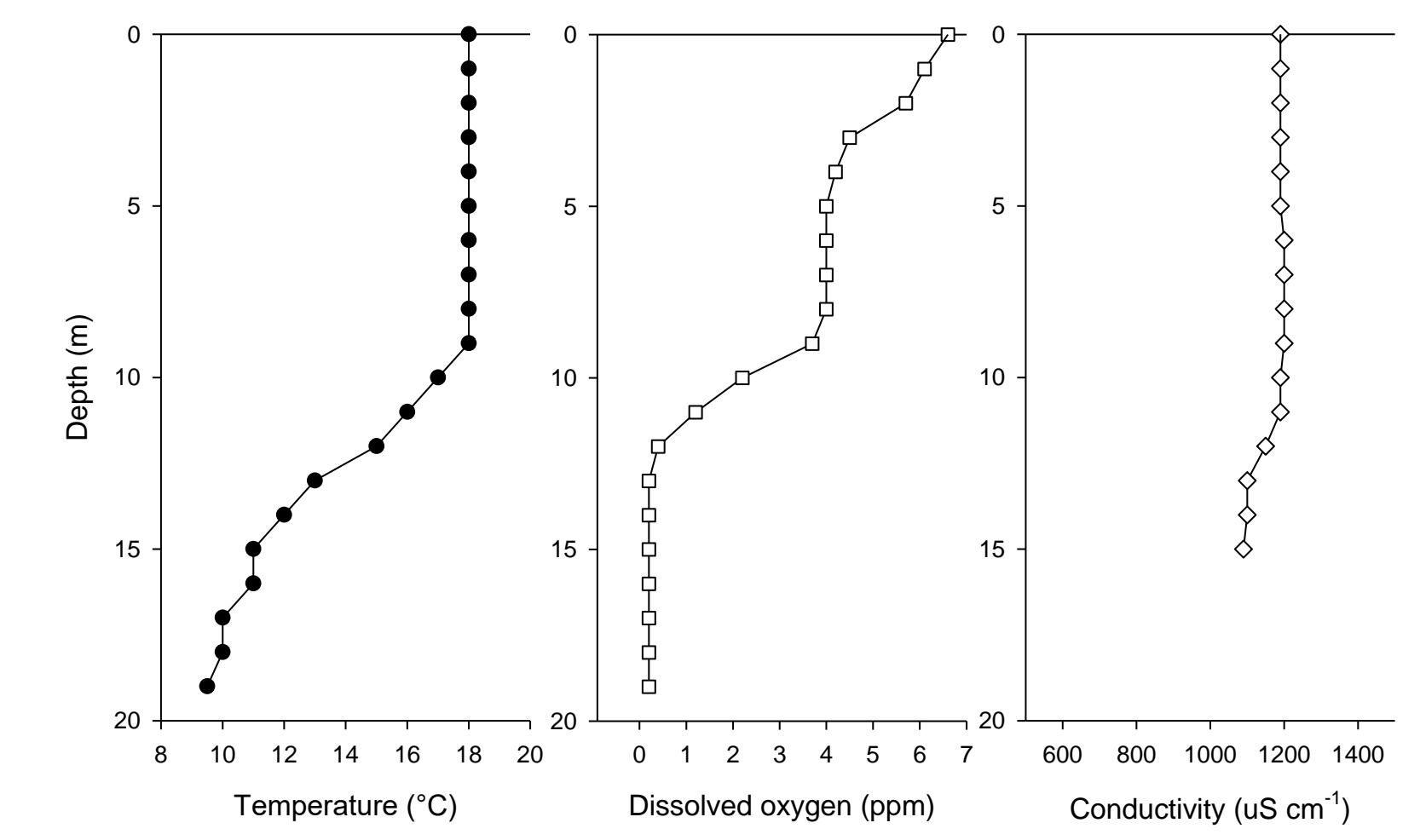

Figure S1. Depth profiles of temperature $\left({ }^{\circ} \mathrm{C}\right)$, dissolved oxygen concentrations (ppm) and conductivity $\left(\mu \mathrm{S} \mathrm{cm}{ }^{-1}\right)$ at the deepest point of Katepwa Lake. 